Gut, 1987, 28, S1, 227-232

\title{
Effect of somatostatin on the growth of gastrointestinal mucosa and pancreas in rats. Role of endogenous gastrin
}

\author{
A DEMBIŃSKI, Z WARZECHA, S J KONTUREK, AND A V SCHALLY \\ From the Institute of Physiology, Medical Academy, Kraków, Poland, and Veterans Administration Center, \\ New Orleans, La, USA
}

SUMMARY This study was undertaken to determine the influence of somatostatin on the growth of gastric, duodenal, and pancreatic tissue in rats placed on liquid diet. In the first part of the study animals were fed an elemental liquid diet for 10 days and then killed, and the growth of the oxyntic gland area of the stomach, $2 \mathrm{~cm}$ segments of duodenum and pancreatic tissue was determined. Feeding an elemental diet caused a decrease in organ weight, nucleic acid contents and serum gastrin level. Subsequent addition of pentagastrin prevented this reduction in organ weight and RNA and DNA contents while somatostatin failed to affect the decrease in growth parameters or serum gastrin level in tests with or without addition of pentagastrin. In a second part of the study, sham operated and antrectomised rats were used. Antrectomy caused a significant decrease in serum gastrin concentration and resulted in a significant reduction in the weight and RNA and DNA contents of the tissue tested. As in liquid diet, subsequent administration of pentagastrin prevented the reduction in the growth parameters both in tests with and without somatostatin. These results suggest that somatostatin inhibits the growth of the gastroduodenal mucosa by a mechanism involving, at least in part, the suppression of gastrin release.

Somatostatin, a growth hormone-release inhibiting hormone, originally isolated from the hypothalamus, was subsequently detected by immunocytochemistry in the endocrine cells and neurones of gastrointestinal mucosa and the pancreas. ${ }^{12}$ Further studies showed that this hormonal peptide possesses multiple antisecretory actions at both pituitary and extrapituitary sites and affects all basic functions of the digestive system including secretory, motility, absorption and splanchic circulation. ${ }^{3}$

The effects of somatostatin on the growth of gastrointestinal tissues have been little studied. It has been reported that an atrophy of the gastric mucosa was associated with a reduction in somatostatin content in the fundus and the antrum. ${ }^{4}$ Furthermore, a reduction in the DNA synthesis and cell division of the rat stomach has been observed after infusion of somatostatin alone or in combination with gastrin. ${ }^{5}$ Chronic administration of somatostatin in rats was found to decrease DNA, RNA and protein synthesis

Address for correspondence: Prof Dr S J Konturek, Institute of Physiology, 31-531 Kraków, ul Grzegórzecka 16, Poland. and to reduce DNA and enzyme content in the pancreas but these effects were not substantial. ${ }^{6}$

This study was designed to determine the action of somatostatin on growth of the mucosa of gastrointestinal tract and pancreas, and to examine the role of gastrin in these effects.

\section{Methods}

\section{ANIMALS}

Experimental design

Male Sprague-Dawley rats weighing between 170$180 \mathrm{~g}$ were used in these studies. In the first study, 25 rats were divided into five groups and housed in cages with open wire bottoms. The first group was receiving Purina rat chow and the second to the fifth group were placed on a liquid diet (Standard VivonexNorvich-Eaton Pharmaceuticals Norvich, NY), the amounts consumed being monitored each day. The liquid diet consisted of $50 \mathrm{ml} /$ day of solution. Each group consumed at least $85 \%$ of its daily diet allotment. Rats received the diet for 10 days. During 
this period of time rats were injected subcutaneously three times daily: first and second group with saline, third with pentagastrin $250 \mu \mathrm{g} / \mathrm{kg}$, fourth somatostatin $100 \mu \mathrm{g} / \mathrm{kg}$ and fifth a combination of pentagastrin $250 \mu \mathrm{g} / \mathrm{kg}$ and somatostatin $100 \mu \mathrm{g} / \mathrm{kg}$.

In the second study, animals were fasted for 24 hours. Using ether anaesthesia, antrectomy was performed through a midline incision by removing the distal half of the glandular stomach including the entire lesser curvature and $1.5 \mathrm{~cm}$ of the duodenum. Gastrointestinal continuity was reestablished by end to end gastroduodenal anastomosis. Sham operation was performed by opening the abdominal cavity and making an incision and repairing it in the glandural stomach. Survival rate after antrectomy was about $75 \%$. Sufficient number of animals were antrectomised to provide a group of 10 . Antibiotics were not used. Antrectomised rats regained weight to normal levels during the 10 days after surgery. Three weeks after surgery rats were divided into five groups. First sham operated group received only three subcutaneous injections of saline per day for 10 days, second to fifth group of antrectomised rats were injected in the same way as sham operated. Second group received saline, third pentagastrin $250 \mu \mathrm{g} / \mathrm{kg}$, fourth somatostatin $100 \mu \mathrm{g} / \mathrm{kg}$, and fifth a combination of pentagastrin $250 \mu \mathrm{g} / \mathrm{kg}$ and somatostatin $100 \mu \mathrm{g} / \mathrm{kg}$.

All experiments were repeated twice so $n=10$ in each group. All drugs used were dissolved in $0.3 \mathrm{ml}$ of $16 \%$ gelatin. During the last 24 hours of experiments rats were fasted with free access to water.

\section{TISSUE SAMPLES}

Rats were removed from their cages, weighed and anaesthetised with ether. Blood was collected from the aorta and the serum was separated and stored at $-20^{\circ} \mathrm{C}$ for subsequent gastrin radioimmunoassay as described before. ${ }^{?}$

The stomach, duodenum, and pancreas were removed and placed in ice cold saline. The stomach was opened along the greater curvature and washed. The oxyntic gland area was dissected out and weighed. Segments $2 \mathrm{~cm}$ long of duodenum were removed, opened, rinsed and weighed. The $2 \mathrm{~cm}$ duodenum segment was taken about $1 \mathrm{~cm}$ past the pylorus. The mucosa was scraped from tissue samples using a glass microscope slide over a glass plate. Mucosal samples were blotted and weighed. Pancreas was dissected out, weighed and minced.

\section{TISSUE MEASUREMENTS}

Mucosal samples were washed twice in $0.2 \mathrm{~N}$ perchloric acid and centrifuged $500 \mathrm{~g}$ for 10 minutes. RNA was hydrolysed quantitatively in $0.3 \mathrm{~N} \mathrm{KOH}$ and incubated at $37^{\circ} \mathrm{C}$ for 90 minutes. DNA and protein were precipitated with $2 \mathrm{ml}$ perchloric acid. After standing for 10 minutes in ice the tubes were centifuged and the supernatant collected. The pellets were resuspended, washed with $4 \mathrm{ml} 0.2 \mathrm{~N}$ perchloric acid and centrifuged. Absorbancies of the combined supernatants were calculated according to a formula devised by Munro and Fleck. ${ }^{8}$

The DNA-containing pellet was dissolved in $4 \mathrm{ml}$ $10 \%$ perchloric acid by heating in a boiling water bath for 20 minutes. Denaturated protein was removed by centrifugation for 20 minutes and filtration through Whatman no. 50 filter. Using calf thymus DNA as a standard, the DNA content of the filtrate was measured using the procedure described by Burton ${ }^{9}$ and modified by Giles and Myers. ${ }^{10}$ DNA and RNA were expressed as milligrams per total organ weight: oxyntic gland area of the stomach, per $2 \mathrm{~cm}$ of duodenum and pancreas.

\section{GASTRIN RADIOIMMUNOASSAY}

Gastrin was measured according to the method outlined by Yalow and Berson ${ }^{11}$ using an antibody to gastrin kindly donated by Professor I F Rehfeld, Aarhus, Denmark at a final dilution of 1:100000. With this antibody, all major forms of gastrin were measured on nearly equimolar basis. The assay system was sufficiently sensitive to detect $1 \mathrm{pM}$ of serum gastrin.

The results are presented as means \pm SEM. The mean responses to each stimulant in the different stages were compared by the $t$ test and differences were regarded as significant if $\mathrm{p}<0.05$.

\section{Results}

In the first study liquid diet significantly decreased the weight of the oxyntic gland area of the stomach (Fig. 1). Similar results were obtained when rats were treated additionally with somatostatin. When rats placed on a liquid diet received pentagastrin the weight of the oxyntic gland reached a significantly higher level than those treated with $\mathrm{NaCl}$ or receiving regular Purina rat chow. This increase was the same when pentagastrin was injected in a combination with somatostatin. In the oxyntic mucosa, RNA and DNA decreased in rats placed on liquid diet by about $32 \%$ and $29 \%$ respectively. Pentagastrin prevented these changes. When rats fed liquid diet received pentagastrin together with somatostatin, RNA and DNA contents remained the same as in animals treated with pentagastrin alone. As RNA and DNA changed proportionally in all tested groups of rats, the RNA/ DNA ratio remained unchanged (data not shown).

Figure 2 lists the organ weight and nucleic acid content in the duodenum. In general, somatostatin caused similar changes in weight and DNA and RNA 
Oxyntic gland area
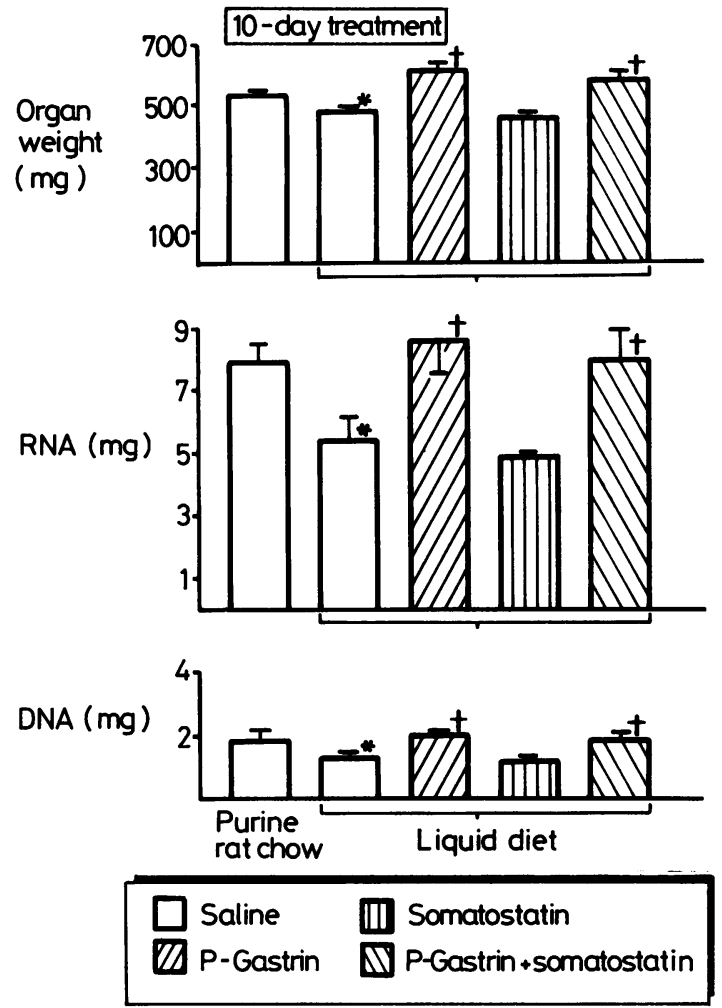

Fig. 1 Weight, RNA and DNA contents of oxyntic gland area of stomach. Somatostatin was injected three times a day in the dose $100 \mu \mathrm{g} / \mathrm{kg}$ for 10 days. Pentagastrin was injected the same manner in the dose $250 \mu \mathrm{g} / \mathrm{kg}$. Bars represent means: vertical lines SEM of 10 animals in each group $* p<0.05$ compared with Purina rat chow.

$\dagger p<0.025$ compared with saline.

contents in the duodenum as in gastric mucosa. Liquid diet caused a decrease in the weight, RNA and DNA contents, while adding pentagastrin completely prevented these changes. In fact, the weight and nucleic acid contents of the mucosa of rats on liquid diet fed animals but receiving pentagastrin were significantly greater than the comparable values for the Purina rat chow fed rats. A similar increase was observed in the group injected with the combination of pentagastrin and somatostatin in rats placed on liquid diet, somatostatin alone was without any effect if compared with $\mathrm{NaCl}$ injected rats.

In the pancreas, the liquid diet decreased pancreatic weight (Fig. 3). A similar decrease was obtained when rats were additionally treated with somatostatin. When rats were injected with pentagastrin we obtained significant increase in the pancreatic tissue weight. Somatostatin added to pentagastrin did not
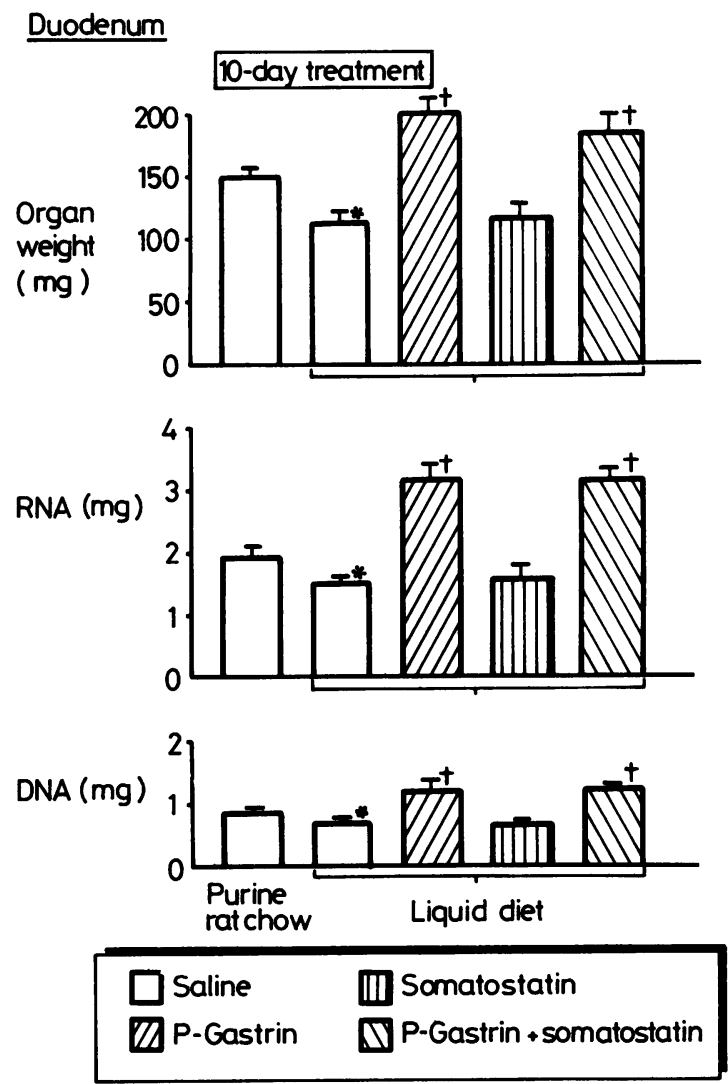

Fig. 2 Weight, RNA and DNA contents of $2 \mathrm{~cm}$ segment of duodenum from the experiments described in Fig. 1 . Mean \pm SEM of 10 animals ${ }^{*} p<0.05$ compared with Purina rat chow. $\dagger p<0.025$ compared with saline.

cause any changes in organ weight when compared with pentagastrin alone.

Liquid diet resulted in a small but not significant decrease in DNA content that differed from the results obtained in the stomach and duodenum. As in gastric and duodenal mucosa, pentagastrin alone and in combination with somatostatin increased significantly the RNA and DNA contents in the pancreas. Somatostatin alone in rats on a liquid diet did not cause any changes compared with control.

Basal concentration of gastrin in rats fed Purina rat chow averaged $135 \pm 6 \mathrm{pM}$ (Fig. 4). Feeding liquid diet caused a decrease in serum gastrin in both saline and somatostatin treated groups. Serum gastrin concentrations of the sham operated control were approximately $145 \mathrm{pM}$ and did not differ from the control group. Antrectomy decreased gastrin to about $40 \%$ of sham operated control animals $\mathrm{p}<0.01$. 


\section{Pancreas}
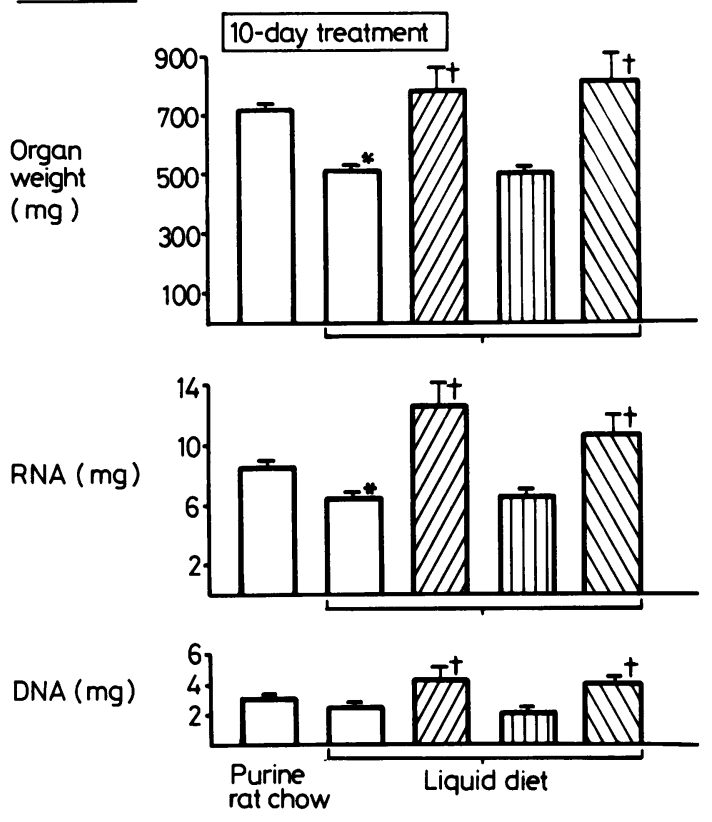

$$
\begin{aligned}
& \square \text { Saline } \quad \text { Somatostatin } \\
& \text { W P-Gastrin } \mathbb{D}_{\text {P-Gastrin+somatostatin }}
\end{aligned}
$$

Fig. 3 Pancreatic weight, RNA and DNA contents from the experiments described in Fig. $1 .{ }^{*} p<0.05$ compared with Purina rat chow. $\dagger p<0.05$ compared with saline.

The Table shows that the content of both RNA and DNA in the antrectomised rats decreased significantly both in the stomach and duodenum. Injections of

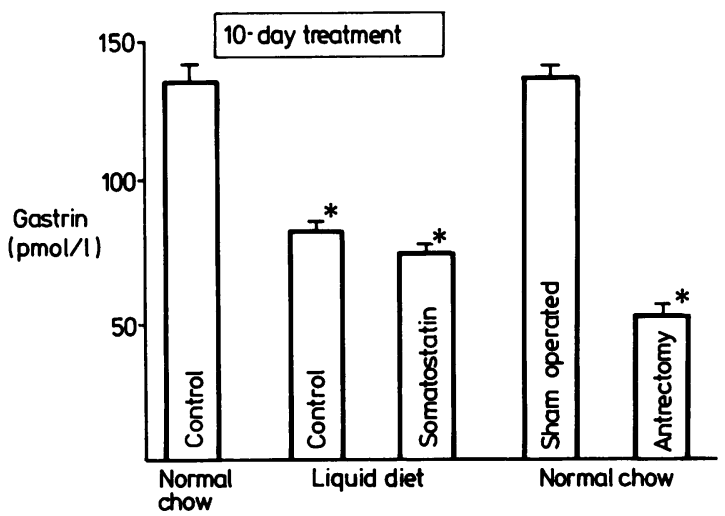

Fig. 4 Serum gastrin concentrations from rats fed solid food and liquid diet Vivonex. Somatostatin $100 \mu \mathrm{g} / \mathrm{kg}$ was injected three times a day for 10 days. Bars represent means: vertical lines SEM of 10 animals in each group ${ }^{*} p<0.02$ compared with control. On the right side of the figure serum gastrin concentrations in sham operated controls and antrectomised rats. $\dagger p<0.001$ compared with sham operated control.

somatostatin in the dose $100 \mu \mathrm{g} / \mathrm{kg}$ did not cause additional changes in any of the parameters studied. Pentagastrin raised the RNA and DNA contents in the oxyntic gland and duodenal mucosa to the values similar to those obtained in sham operated rats. Subsequent addition of somatostatin was without any inhibitory effect. Also the RNA/DNA ratio remained unchanged in all groups of animals.

In the pancreatic tissue RNA and DNA were also significantly suppressed after antrectomy. Addition of pentagastrin prevented these changes. Somatostatin

Table RNA and DNA contents in the stomach, duodenum and pancreas after antrectomy and treatment with pentagastrin

\begin{tabular}{|c|c|c|c|c|c|c|}
\hline \multirow[b]{2}{*}{ Organ } & \multirow[b]{2}{*}{ Parameters } & \multicolumn{5}{|l|}{ Group } \\
\hline & & Control & Antrectomy & $\begin{array}{l}\text { Antrectomy }+ \\
\text { somatostatin }\end{array}$ & $\begin{array}{l}\text { Antrectomy + } \\
\text { pentagastrin }\end{array}$ & $\begin{array}{l}\text { Antrectomy }+ \\
\text { P-gast. }+ \text { somatost. }\end{array}$ \\
\hline \multirow[t]{3}{*}{ Stomach } & $\begin{array}{l}\text { RNA mg/oxyntic } \\
\text { gland }\end{array}$ & $6 \cdot 76 \pm 0.21$ & $4.89 \pm 0.89^{*}$ & $4 \cdot 72 \pm 0.37^{*}$ & $6.93 \pm 0.18 \dagger$ & $6.83 \pm 0.09 \dagger$ \\
\hline & $\begin{array}{l}\text { DNA mg/oxyntic } \\
\text { gland }\end{array}$ & $2 \cdot 11 \pm 0 \cdot 15$ & $1.49 \pm 0.05^{*}$ & $1 \cdot 31 \pm 0.06^{*}$ & $2 \cdot 04 \pm 0 \cdot 10 \dagger$ & $1.91 \pm 0.05 \dagger$ \\
\hline & RNA/DNA & $3 \cdot 13 \pm 0.21$ & $3 \cdot 26 \pm 0 \cdot 14$ & $3.40 \pm 0.14$ & $3.42 \pm 0.23$ & $3.42 \pm 0.19$ \\
\hline \multirow[t]{2}{*}{ Duodenum } & $\begin{array}{l}\text { RNA mg/2 cm } \\
\text { segment }\end{array}$ & $1.70 \pm 0.53$ & $1.29 \pm 0.06^{*}$ & $1 \cdot 30 \pm 0 \cdot 10^{*}$ & $1.70 \pm 0.06 \dagger$ & $1.62 \pm 0.08 \dagger$ \\
\hline & $\begin{array}{l}\text { DNA mg/2 cm } \\
\text { segment }\end{array}$ & $0.74 \pm 0.07$ & $0.51 \pm 0.03^{*}$ & $0 \cdot 49 \pm 0.04^{*}$ & $0.74 \pm 0.07 \dagger$ & $0.62 \pm 0.05 \dagger$ \\
\hline Pancreas & $\begin{array}{l}\text { RNA/DNA } \\
\text { RNA mg/total } \\
\text { DNA mg/total } \\
\text { RNA/DNA }\end{array}$ & $\begin{array}{l}2.39 \pm 0.07 \\
7.86 \pm 0.21 \\
3.03 \pm 0.25 \\
2.69 \pm 0.11\end{array}$ & $\begin{array}{l}2.53 \pm 0.09 \\
7 \cdot 18 \pm 0.23^{*} \\
2.44 \pm 0.19^{*} \\
3.01 \pm 0.29\end{array}$ & $\begin{array}{l}2.66 \pm 0.08 \\
7.01 \pm 0.33^{*} \\
2.32 \pm 0.20^{*} \\
2.96 \pm 0.23\end{array}$ & $\begin{array}{l}2.39 \pm 0.07 \\
8.41 \pm 0.31 \dagger \\
3.24 \pm 0.21 \dagger \\
2.66 \pm 0.26\end{array}$ & $\begin{array}{l}2.62 \pm 0.11 \\
7.96 \pm 0.21 \dagger \\
3 \cdot 19 \pm 0.18 \dagger \\
2.59 \pm 0.30\end{array}$ \\
\hline
\end{tabular}
$250 \mu \mathrm{g} / \mathrm{kg}$, somatostatin $100 \mu \mathrm{g} / \mathrm{kg}$ or combination of both.

Values are means $\pm S E M ; n=10$ animals in each group; ${ }^{*} p<0.025$ compared with control; $\dagger p<0.025$ compared with antrectomised rats. 
alone was without any significant effect on the RNA and DNA contents and injected together with pentagastrin did not show any inhibitory action.

\section{Discussion}

In several mammalian species, including rats, somatostatin was reported to be capable of inhibiting both the release of gastrin and its stimulatory action on gastric acid secretion. ${ }^{1213}$

The physiological role of somatostatin in the control of antral gastrin release was suggested by others ${ }^{14}$ showing that the infusion of somatostatin antiserum produced acute increase in venous gastrin concentration. The effect of somatostatin on the mucosal growth has been little studied. Our preliminary studies (data unpublished) indicate that somatostatin decreases significantly the weight and the RNA and DNA contents in the mucosa of the oxyntic gland area of the stomach, the duodenum and the colon. In addition Morisset ${ }^{15}$ showed that in the pancreas somatostatin is a potent endogenous antigrowth factor.

The present study shows that liquid diet decreases significantly the weight of the mucosa of the stomach, the duodenum and the pancreas. This effect was accompanied by a decrease in total contents RNA and DNA without significant changes in RNA/DNA ratio indicating hypoplastic changes produced by liquid diet. Feeding an elemental Vivonex diet in rats is known to cause a decrease in rate of cell division and the reduction of villous size in both jejunum and ileum as compared with rats fed regular Purina chow. ${ }^{16}$ In our study, the changes in gastroduodenal mucosa and pancreatic tissue were well correlated with the alteration in serum gastrin concentrations. It is suggested that the inhibition of the growth of gastroduodenal mucosa and pancreatic tissue seen in our study was caused by the reduction in plasma gastrin caused by inhibition or to a decrease of gastrin release.

In rats on liquid diet, DNA content in the pancreas was somewhat lower than in rats fed Purina rat chow but this was not statistically significant. The reason for this could be due to the small decrease in endogenous gastrin level was not sufficient for the decrease of growth of pancreatic tissue. In the antrectomised rats which showed deeper decrease in gastrin level, the DNA content in pancreas was depressed significantly. Our present results on the effects of endogenous gastrin on the pancreatic growth are consistent with previous reports ${ }^{17-19}$ including our earlier study ${ }^{20}$ showing a decrease on pancreatic growth after antrectomy and reversion of this effect after addition of exogenous gastrin. There are, however, several studies which do not support the role of endogenous gastrin on the pancreatic growth. After antrocolitic transposition in rats in which an approximate eight-fold increase in the gastrin levels occurred no increase in the pancreatic weight or DNA concentration was observed. ${ }^{21}$ Another study ${ }^{22}$ with hypergastrinaemia caused by vagotomy or hypogastrinaemia resulting from antrectomy also failed to affect the pancreas weight and DNA or protein contents.

As serum gastrin concentration after somatostatin administration in rats is known to be significantly lowered, ${ }^{23}$ we were interested to check whether somatostatin inhibits the growth of the gastroduodenal mucosa directly or whether this effect is mediated by the suppression of endogenous gastrin. In our previous study ${ }^{20}$ we observed an atrophy in the oxyntic gland and duodenal mucosa and pancreas after antrectomy in which the major source of gastrin is removed. Furthermore, it was shown that the hypophysectomy induced hypoplasia of the gastric mucosa was also accompanied by a diminution of serum gastrin concentration suggesting that the trophic action of growth hormone on the gastric tissue is mediated by gastrin. ${ }^{24}$

Somatostatin could suppress the release of both the growth hormone and gastrin required for cell proliferation in the gastric mucosa.

We found that the serum gastrin concentration in rats fed an elemental diet and after antrectomy was significantly reduced. It is reasonable to assume, therefore, that the decrease in serum gastrin release could explain, at least in part, the reduction in the growth of the gastroduodenal mucosa observed in these experiments.

If somatostatin was acting directly without mediation of gastrin, we would see a reduction in organ weight and RNA and DNA contents of the gastroduodenal mucosa and the pancreatic tissue in rats treated with somatostatin and placed on liquid diet or antrectomised. This was, however, not the case as somatostatin did not inhibit the growth of the mucosa in rats on liquid diet when serum gastrin level was already reduced. Similarly, somatostatin did not affect the inhibition of mucosal growth in antrectomised animals in which plasma gastrin concentration was decreased to a similar degree as in animals placed on the liquid diet. The question still remains, however, whether somatostatin is inhibiting the release or the action of gastrin or both.

In accordance with previous reports, ${ }^{25}{ }^{26}$ pentagastrin in our present study increased the weight, and the RNA and DNA contents in all tissues tested in animals on both regular and liquid diet. Subsequent addition of somatostatin did not affect this action. This suggests that somatostatin is unable to affect the growth promoting action of gastrin on the gastro- 
duodenal mucosa and, thus, the only mechanism of it is the inhibition of the release of endogenous gastrin. On the other hand, starvation and a special diet led to a decrease in the number of antral G-cells that reacted with fluorescent antigastrin antiserum. ${ }^{27}$ Under these conditions the number of target cells for somatostatin was decreased.

In summary somatostatin appears to be unable to act on the growth of gastrointestinal mucosa and pancreatic tissue when endogenous gastrin level is low and does not inhibit the trophic action of exogenous gastrin. These results suggest that the action of somatostatin is mediated via synthesis or release of endogenous gastrin. Whether the suppression of gastrin release by somatostatin has an antitrophic effect or whether it also acts directly on the cell proliferation and mucosal growth remains to be established.

\section{References}

1 Arimura A, Sato H, Dupont A, Nishi N, Schally AV. Somatostatin: abundance of immunoreactive hormone in rat stomach and pancreas. Science 1975; 189: 1007 9.

2 Polak JM, Pears AGE, Grimelius E, Bloom SR, Arimura A. Growth-hormone release-inhibiting hormone in gastrointestinal and pancreatic D-cells. Lancet 1975; i: 1220-2.

3 Konturek SJ. Somatostatin and the digestive system. Gastroenterol Clin Biol 1977; 1 : 849-54.

4 Chayvialle JAP, Descas F, Bernard C, Martin A, Barbe $\mathrm{C}$, Partensky C. Somatostatin in mucosa of stomach and duodenum in gastrointestinal disease. Gastroenterology 1978; 75: 13-9.

5 Lehy T, Dubrasquet M, Bonfils S. Effect of somatostatin on hormonal and gastrin-stimulated proliferation in the gastric and intestinal mucosae of rats. Digestion 1979; 19: 99-109.

6 Morisset J, Genik P, Solomon TE. Effect of chronic administration of somatostatin on rat exocrine pancreas. Regulat Peptides 1982; 4: 49-58.

7 Fokina A, Konturek SJ, Kwiecien N, Radecki T. Role of gastric antrum in gastric and intestinal phases of gastric secretion in dogs. J Physiol 1979; 295: 229-39.

8 Munro HN, Fleck A. Recent developments in the measurement of nucleic acid in biological materials. Analyst 1966; 91 : 78-89.

9 Burton K. A study of the conditions and mechanisms of the diphenylamine reaction for the colorimetric estimation of deoxyribonucleic acid. Biochem J 1956; 62: 31523.

10 Giles KW, Myers A. An improved diphenylamine method for the estimation of deoxyribonucleic acid. Nature (Lond) 1965; 206: 93.

11 Yalow RS, Berson SA. Radioimmunoassay of gastrin. Gastroenterology 1970; 58: 1-14.

12 Barros D'sa AAJ, Bloom SR, Baron J. Direct inhibition of gastric acid by growth-hormone release-inhibiting hormone in dog. Lancet 1975; ii: 886-90.

13 Dubrasquet M, Accory JP, Robein HJ, Bonfils S. Somatostatin: evaluation of inhibitory effects in rats with chronic hypergastrinaemia. [Abstract]. Gastroenterology 1976; 70: 881.

14 Saffouri B, Weir G, Bitar K, Makklouf G. Stimulation of gastrin secretion from the perfused rat stomach: functional linkage of antral peptides. Am J Physiol 1980; 239: G495-501.

15 Morisset J. Somatostatin: a potential antigrowth factor for the exocrine pancreas. Regulat Peptides 1984; 10: 11-22.

16 Ecknauer R, Siricar B, Johnson LR. Effect of dietary bulk on small intestinal morphology and cell renewal in the rat. Gastroenterology 1981; 81: 781-6.

17 Koop H, Schwarting H, Trautman M, et al. Trophic effect of truncal vagotomy on the rat pancreas. Digestion 1986; 33: 198-205.

18 Johnson LR. Effect of gastrointestinal hormones on pancreatic growth. Cancer 1981; 47: 1640-5.

19 Büchler, M, Malfertheiner P, Eiberle E, Feurle GE, Beger HG. Gastrointestinal hormones influence pancreatic trophism following distal gut removal in the rat. Digestion 1986; 35: 11.

20 Dembiníski AB, Johnson LR. Growth of pancreas and gastrointestinal mucosa in antrectomized and gastrintreated rats. Endocrinology 1979; 105: 769-73.

21 Reber HA, Johnson F, Deveney K, Montgomery C, Way LW. Trophic effects of gastrin on the exocrine pancreas in rats. J Surg Res 1977; 22: 554-60.

22 Stock-Damge C, Lhoste E, Aprahamian A. Gastrin modulation of pancreatic growth. Scan J Gastroenterol 1985; 20 suppl 112: 68-74.

23 Bloom SR, Mortimer CH, Therner MO, et al. Inhibition of gastrin and gastric acid secretion by growth hormone release-inhibiting hormone. Lancet 1974; ii: 1106-9.

24 Crean GP, Rumsey RDE, Weeler S. Further observations concerning the effect of hypophysectomy on gastric mucosa of the rat. Gut 1971; 12: 721-6.

25 Johnson LR. Regulation of gastrointestinal growth. In: Johnson LR, ed. Physiology of the gastrointestinal tract. New York: Raven Press, 1981: 169-96.

26 Johnson LR, Lichtenberger LM, Copeland EM, Durick SJ, Castro AG. Action of gastrin on gastrointestinal structure and function. Gastroenterology 1975; 68: 1184-92.

27 Lichtenberger LM, Lechago J, Johnson LR. Depression of antral and serum gastrin concentration by food depravation in the rat. Gastroenterology 1975; 68: 1473-9. 